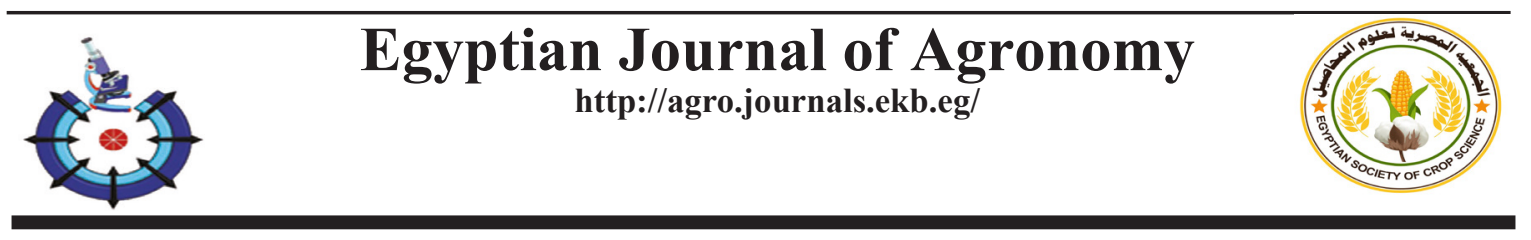

\title{
Possibility of Sugar Beet Production in Toshka Region. II- Effect of Water Stress on Some Sugar Beet Varieties
}

\author{
A.O. Awadalla ${ }^{(1) \#}$, A.Z. Ahmed ${ }^{(2)}$, Mohammad M. Shereif ${ }^{(3)}$ \\ ${ }^{(1)}$ Faculty of Agriculture and Natural Resources, Aswan University, Aswan, Egypt; \\ ${ }^{(2)}$ Sugar Crops Researc. Institute., Agricultural Research Center(ARC), Giza, Egypt; \\ (3) Water Studies and Research Complex, National Water Research Center (NWRC), \\ Egypt.
}

$\mathbf{T}$ WO field experiments were carried out during 2016/2017 and 2017/2018 seasons at the agricultural experimental station farm of Water Studies \& Research Complex (WSRC), National Water Research Center, located in Abu-Simbel, Toshka, at the most southern part of Egypt, about 1300 south from Cairo and $280 \mathrm{Km}$ from Aswan (latitude of $22^{\circ} .49^{-} \mathrm{N}$, longitude of $28^{\circ} .58^{-}$E) Aswan Governorate, Egypt. These trials aimed to find out the effect of water stress rates $(60 \%, 80 \%$ and $100 \%$ of irrigation water requirements (IWR). on yield, yield components and quality of sugar beet varieties namely Oscar poly, Farida, and Universal. Randomized complete block design, in Strip Plots arrangement, with three replications was used.

Results indicated that water stress treaments were significantly influenced all the studied characters. Also results revealed that irrigated sugar beet plants with $100 \%$ of IWR recorded the highest root length, diameter, weight, sucrose $\%$, extractable sugar $\%$ and extractability $\%$ as well as root and sugar yields, while it gave the lowest mean values of impurities and sugars lost to molasses percentages.

Also results showed that the differences among the examined varieties were significant with respect to all studied traits. Results indicated that variety of Oscar poly surpassed the other two varieties in root yield and its yield components, However, Universal variety surpassed the other varieties in sucrose, extractable, extractability percentages and sugar yield.

Under conditions of Toshka region, the results suggested that planting Universal beet variety, with $100 \%$ of the irrigation water requirement can be recommended to produce the best quality as well as the highest root and sugar yields/ha.

Keywords: Irrigation, Roots deficit, Sugar beet, Variety, Water requirement, Yield.

\section{Introduction}

In Egypt, the yearly national production of sugar, 2.28 million tons, fails to cover the consumption amounted to3.25 million tons (S. C. C., 2020). As an attempt to minimize this gap, it was necessary to expand the area planted with sugar beet in the newly reclaimed lands. This work was conducted to evaluate the performance of three beet varieties under water stress to find out the best variety and its proper water requirement to get the maximum root and sugar yields per unit area in Toshka zone.
Maximizing sugar production is a national target through expansion in sugar beet cultivation in the newly reclaimed soils, the specific problems of newly reclaimed soils management in particular their low water holding capacity require using an efficient irrigation system such as controlled irrigation. This technique makes it possible to relate, under water shortage condsitions, the drought stress undergone by the sugar beet plants to possible decreases in the yield or quality. The performance of beet plants under controlled irrigation with respect to yield and its components was studied by many authors among them, Tognetti et al. (2002),

"Corresponding author email: abdelmoneim.awadallah@agr.aswu.edu.eg

Received 20/10/2021; Accepted 10/1/2022

DOI : 10.21608/agro.2022.102043.1286

C2021 National Information and Documentation Center (NIDOC) 
Mahmoodi et al. (2008), Al-Sayed et al. (2014), Masri et al. (2015), Abd El-All \& Makhlouf (2017), Attaya (2017), El Hamdi et al (2017) and Nilahyane et al. (2020).

Much interest is directed to import, evaluate and select high yielding sugar beet varieties, newly selected varieties differ in performance according to its genetic makeup and the environment in which they grow. Sugar beet arieties differences in yield and quality characteristics are extensively reported in literature (Mekdad \& El-Sherif, 2016; Ahmed et al., 2017; El-Emary, 2017; Sadek et al., 2019; Mohamed \& El-Sebai, 2019; Teama et al., 2019; Kandil et al., 2020; El-Safy et al., 2020).

The main objective of this investigation was to determine the optimum irrigation rate $(60,80$ and $100 \%$ of the full irrigation water requirement (IWR) for three sugar beet varieties under Toshka region condition.

\section{Materials and Methods}

In this concern, this research work is the second to be conducted in Toshka zone.

Two field trails were carried out at the Water Studies and Research Complex Abu Simbel, (latitude of $22^{\circ} .49^{-} \mathrm{N}$, longitude of $28^{\circ} .58^{-} \mathrm{E}$ ) Aswan Governorate, Egypt. in 2016-2017 and 2017-2018 seasons to find out to study the response of some sugar beet varieties to water stress, under Toshka region condition. The field trait included nine treatments represent the combination of three water stress rates $(60,80$ and $100 \%$ of the full irrigation water requirement (IWR) as well as three sugar beet varieties namely Oscar poly, Farida and Universal.
Randomized complete block design, in strip plots arrangement, with three replications was used, where irrigation rates were allocated in the horizontal, while sugar beet varieties were randomly distributed in the vertical, each sub plot was $21 \mathrm{~m}^{2}$ (including six ridges of $0.5 \mathrm{~m}$ in width and $7.0 \mathrm{~m}$ in length). Sugar beet was planted on first week of October in both seasons. Manual planting was achieved in hills with approximately 3-4 seeds/ hill and then plants were thinned at four leaf stage (at age of 45 days) to obtain one plant/hill. Mean of temperature and relative humidity $\%$ are presented in Table 1.

Phosphorus fertilizer (as calcium super phosphate $15.5 \% \mathrm{P}_{2} \mathrm{O}_{5}$ ) at the rate of $107 \mathrm{~kg} /$ ha was added during land preparation. Nitrogen fertilizer (as ammonium nitrate $33.5 \% \mathrm{~N}$ ) at the rate of $238 \mathrm{~kg} / \mathrm{ha}$. was applied in four equal portions, the first was applied after thinning and 15 days between the others. Potassium fertilizer (as potassium sulfate $48 \% \mathrm{~K}_{2} \mathrm{O}$ ) at the rate of $86 \mathrm{~kg} / \mathrm{ha}$ was applied with nitrogen fertilizer. Other agricultural practices required for growing sugar beet were carried out as usually practiced in the region.

The amount of irrigation water requirement was determined using Blaney \& Criddle (1962) method:

$\mathrm{IRc}=[(\mathrm{ETo} \times \mathrm{Kc}) \mathrm{x} \mathrm{Dd}] / \mathrm{Es}$

where:IRc $=$ Totalactualirrigationwaterrequirements $(\mathrm{mm} /$ intervals $), \quad \mathrm{ETo}=$ Evapotranspiration $(\mathrm{mm} /$ day), calculated according to CROPWAT program (Smith, 1991), Kc= Crop coefficient (Doorenbos \& Kassam, 1979), Dd= Time intervals and $\mathrm{Es}=$ System efficiency (\%) (Tables 2, 3).

TABLE 1. Temperature and relative humidity percentage in Toshka region during 2016/2017 and 2017/2018 seasons

\begin{tabular}{|c|c|c|c|c|c|c|c|c|c|c|c|c|}
\hline \multirow{3}{*}{$\begin{array}{l}\text { Season } \\
\text { Months }\end{array}$} & \multicolumn{6}{|c|}{ 2016/2017 season } & \multicolumn{6}{|c|}{$2017 / 2018$ season } \\
\hline & \multicolumn{3}{|c|}{ Temperature ${ }^{\circ} \mathrm{C}$} & \multicolumn{3}{|c|}{ Humidity \% } & \multicolumn{3}{|c|}{ Temperature $^{\circ} \mathrm{C}$} & \multicolumn{3}{|c|}{ Humidity \% } \\
\hline & Max & Min & Av & $\operatorname{Max}$ & Min & Av. & $\operatorname{Max}$ & Min & Av. & Max & Min & Av. \\
\hline October & 31.23 & 15.51 & 23.37 & 40.44 & 16.89 & 28.66 & 30.22 & 15.66 & 22.94 & 49.12 & 16.74 & 32.93 \\
\hline November & 30.33 & 12.2 & 21.26 & 44.26 & 15.99 & 30.12 & 29.91 & 13.25 & 21.58 & 55.12 & 17.54 & 36.33 \\
\hline December & 30.40 & 5.3 & 17.85 & 46.12 & 31.08 & 38.6 & 26.81 & 10.78 & 18.80 & 48.15 & 24.85 & 36.5 \\
\hline January & 24.76 & 10.08 & 17.42 & 44.55 & 30.13 & 37.34 & 23.71 & 8.06 & 15.59 & 49.17 & 15.59 & 32.53 \\
\hline February & 29.75 & 11.93 & 20.84 & 40.5 & 17.3 & 28.9 & 24.86 & 11.09 & 17.98 & 46.99 & 15.43 & 31.21 \\
\hline March & 31.11 & 11.44 & 21.275 & 42.25 & 9.99 & 26.12 & 28.86 & 12.87 & 20.86 & 39.61 & 9.26 & 24.44 \\
\hline April & 37.7 & 20.33 & 29.02 & 20.16 & 3.8 & 11.98 & 33.3 & 16.1 & 23.9 & 25.0 & 4.2 & 14.6 \\
\hline May & 38.5 & 19.5 & 29 & 35.66 & 12.11 & 23.88 & 42.31 & 24.94 & 33.62 & 32.39 & 4.50 & 18.45 \\
\hline
\end{tabular}

Source: Agricultural meteorological station in water studies and research complex station, (NWRC) Toshka Aswan Egypt. J. Agron. 43, No. 3 (2021) 
TABLE 2.Average evapotranspiration (ETo mm/day) at Toshka.

\begin{tabular}{lcccccccc}
\hline Month & Oct.. & Nov. & Dec & Jan. & Feb. & Mar. & Apr. & May \\
\hline ETo $(\mathrm{mm} /$ day $)$ & 4.52 & 5.94 & 7.78 & 8.99 & 9.58 & 10.10 & 10.24 & 10.83 \\
\hline
\end{tabular}

TABLE 3. Crop factor $(\mathrm{Kc})$ through the growing season of sugar beet in the semi-arid region (and mean values of the amounts of the applied water

\begin{tabular}{lccccc}
\hline \multirow{2}{*}{ Growing stage } & \multirow{2}{*}{$\begin{array}{c}\text { Number } \\
\text { of days }\end{array}$} & $\begin{array}{c}\text { Crop } \\
\text { factor }(\mathbf{K c})^{*}\end{array}$ & $\mathbf{6 0 \%}$ & $\mathbf{8 0 \%}$ & $\mathbf{1 0 0 \%}$ \\
\cline { 5 - 6 } & 30 & 0.20 & 298.9 & 398.7 & 498.4 \\
Initial & 60 & 0.60 & 1423.0 & 1897.3 & 2371.7 \\
Crop development & 60 & 1.00 & 2390.7 & 3187.5 & 3984.4 \\
Mid-season & 30 & 0.40 & 1213.8 & 1618.4 & 2023.0 \\
Late-season & 180 & 2.2 & 5326.4 & 7101.9 & 8877.5 \\
Total & & & & & Amount of water $\left(\mathbf{m}^{\mathbf{3}} / \mathbf{h a}^{\prime}\right)$ \\
\hline
\end{tabular}

Recorded data

At harvest (after 180 days from sowing), two guarded ridges of each plots were harvested to determine the following traits:

1. Root length $(\mathrm{cm})$.

2. Root diameter $(\mathrm{cm})$.

3. Root weight $(\mathrm{kg})$.

4. Root yield (Ton/ha).

Plant samples were then sent to the laboratory of quality analyses at Fayoum Sugar Company to determine the following quality characteristics:

5. Sucrose percentage which was estimated in fresh samples of sugar beet root using "Saccharometer" according to the method described by A.O.A.C. (2005).

6. Root impurities in terms of $\alpha$-amino $\mathrm{N}, \mathrm{Na}$ and $\mathrm{K} \%$ (meq $/ 100 \mathrm{~g}$ beet) according to A.O.A.C. (2005).

7. Sugars lost to molasses percentage (SLM \%) was calculated as described by Devillers (1988) using the following equation:

SLM $\%=[0.14(\mathrm{Na}+\mathrm{K})+0.25(\alpha$-amino $\mathrm{N})+$ $0.5]$.

8. Extractable sugar percentage $(\mathrm{ES} \%)$ was calculated using the equation of Dexter et al. (1967) as follows: ES\% $=$ [sucrose\% $\%$-(sugar lost to molasses $\%+0.6)]$.

9. Extractability $=[($ extractable sugar $\% /$ sucrose $\%)$ $\mathrm{x}$ 100].

10. Sugar yield/fad. (ton) was calculated as follows:

Sugar yield/fad. (ton) $=[$ root yield/fad. (ton) $\mathrm{x}$ $\mathrm{ES} \%]$.

The collected data were statistically analyzed according to Snedecor \& Cochran (1981). Treatment means were compared using LSD at $5 \%$ level of probability. Also, simple correlation coefficients and linear regression were computed among studied traits according to Steel \& Torrie (1980).

\section{Results and Discussion}

Root length

Data given in Table 4 reveal that increasing irrigation rate from 60 to 80 , and $100 \%$ of the full irrigation water requirement (IWR) significantly increase gradually root length in both seasons.

The results cleared that irrigated with $100 \%$ of (IWR) increased the mean value of root length by $4.9 \mathrm{~cm}$ and $4.2 \mathrm{~cm}$ over that of $60 \%$ of (IWR), in the $1^{\text {st }}$ and $2^{\text {nd }}$ seasons, respectively. These results may be due to the fact that water is an essential factor for the turgidity of leaf cells, lengthening of root cells as well as photosynthesis process. These findings are in accordance with those found by AlSayed et al. (2014), Attaya (2017) and El Hamdi et al. (2017), they noted that the highest root length was obtained under the deficit irrigation level of $80 \%$ from IWR.

Also, results cleared that the evaluated varieties varied differed significantly in root length in the $1^{\text {st }}$ and $2^{\text {nd }}$ seasons. Oscar poly showed superiority and a significant variance over the other two varieties in this trait. These results may 
be due to the genetic differences among varieties in their performance. Mekdad \& El-Sherif (2016), Mohamed \& El-Sebai (2019), Teama et al. (2019), and El-Safy et al. (2020) found that the classic variety recorded the highest mean values of root length.

The interaction between varieties and irrigation rate had a significant effect on root length. The varieties did not behave the same under the three irrigation rate. In $1^{\text {st }}$ season the increase in root length of Farida variety was about double of that obtained with Universal variety due to increasing the irrigation rate from 80 to $100 \%$ of (IWR). In general the tallest root was recorded with Oscar poly variety, when irrigated by 100 in both seasons.

\section{Root diameter}

Data in Table 5 cleared that root diameter was significantly affected by irrigation levels in both seasons. Increasing irrigation level to $100 \%$ of the full irrigation water requirement increased significantly values of diameter. Highest irrigation levels recorded the thicker roots $(13.7 \mathrm{~cm}$ and $13.9 \mathrm{~cm})$ and the thinnest roots $(11.7$ and $12.0 \mathrm{~cm})$ were obtained by the lowest one in the two seasons, respectively. These results are in agreement with those obtained by Al-Sayed et al. (2014), Abd ElAll \& Makhlouf (2017) and Attaya (2017) who reported that root diameter of sugar beet varieties significantly affected by the examined irrigation rates in both growing seasons.

Results collected in the same Table indicated that the tested sugar beet varieties differed significantly in root diameter in both seasons. The highest and the lowest mean values of root diameter were recorded with Oscar poly and Farida varieties respectively. This superior Oscar poly variety may be due to the genetic structure of These results are in harmony with those reported by El-Emary (2017), Sadek et al. (2019), Mohamed \& El-Sebai (2019) and Kandil et al. (2020) who noted that there was a significant difference among the three sugar beet varieties in root diameter.

TABLE 4. Root length (cm) of sugar beet varieties as affected by different deficit water levels in 2016/2017 and 2017/2018

\begin{tabular}{|c|c|c|c|c|c|c|c|c|}
\hline \multirow{3}{*}{$\begin{array}{l}\text { Irrigation } \\
\text { water } \\
\text { applied }\end{array}$} & \multicolumn{3}{|c|}{$2016 / 2017$} & \multirow{3}{*}{ Mean } & \multicolumn{3}{|c|}{$2017 / 2018$} & \multirow{3}{*}{ Mean } \\
\hline & \multicolumn{3}{|c|}{ Varieties } & & \multicolumn{3}{|c|}{ Varieties } & \\
\hline & Oscar poly & Farida & Universal & & $\begin{array}{c}\text { Oscar } \\
\text { poly }\end{array}$ & Farida & Universal & \\
\hline $60 \%$ & 28.3 & 25.3 & 24.7 & 26.1 & 27.7 & 24.3 & 25.7 & 25.9 \\
\hline $80 \%$ & 30.3 & 26.0 & 27.0 & 27.8 & 30.3 & 27.0 & 28.0 & 28.4 \\
\hline $100 \%$ & 33.3 & 30.3 & 29.3 & 31.0 & 33.0 & 29.0 & 28.3 & 30.1 \\
\hline Mean & 30.7 & 27.2 & 27.0 & & 30.3 & 26.8 & 27.3 & \\
\hline \multicolumn{9}{|c|}{ LSD.at 0.05 level for } \\
\hline \multicolumn{3}{|c|}{ Irrigation water applied (A) } & & 1.3 & & & & 1.5 \\
\hline \multicolumn{3}{|c|}{ Sugar beet varieties (B) } & & 2.8 & & & & 2.8 \\
\hline \multicolumn{4}{|l|}{$A \times B$} & 2.6 & & & & 2.1 \\
\hline
\end{tabular}

TABLE 5. Root diameter $(\mathrm{cm})$ of sugar beet varieties as affected by different deficit water levels in $2016 / 2017$ and 2017/2018

\begin{tabular}{|c|c|c|c|c|c|c|c|c|}
\hline \multirow{3}{*}{$\begin{array}{l}\text { Irrigation } \\
\text { water } \\
\text { applied }\end{array}$} & \multirow{2}{*}{\multicolumn{3}{|c|}{$\begin{array}{c}2016 / 2017 \\
\text { Varieties } \\
\end{array}$}} & \multirow{3}{*}{ Mean } & \multirow{2}{*}{\multicolumn{3}{|c|}{$\begin{array}{c}2017 / 2018 \\
\text { Varieties } \\
\end{array}$}} & \multirow{3}{*}{ Mean } \\
\hline & & & & & & & & \\
\hline & Oscar poly & Farida & Universal & & Oscar poly & Farida & Universal & \\
\hline $80 \%$ & 14.0 & 12.3 & 13.3 & 13.2 & 14.0 & 13.6 & 12.4 & 13.3 \\
\hline $100 \%$ & 15.0 & 13.7 & 13.3 & 14.0 & 15.0 & 13.7 & 13.0 & 13.9 \\
\hline \multicolumn{9}{|c|}{ LSD.at 0.05 level for } \\
\hline \multicolumn{3}{|c|}{ Irrigation water applied (A) } & & 0.9 & & & & 1.0 \\
\hline \multicolumn{3}{|c|}{ Sugar beet varieties (B) } & & 1.1 & & & & 1.1 \\
\hline \multicolumn{3}{|l|}{$A \times B$} & & 1.15 & & & & 1.6 \\
\hline
\end{tabular}

Egypt. J. Agron. 43, No. 3 (2021) 
The interaction between varieties and irrigation rate had a significant effect on root diameter. The varieties did not behave the same under the three irrigation rate. In $1^{\text {st }}$ season the increase in root diameter of Oscar poly variety was about double of that obtained with Farida variety due to increasing the irrigation rate from 60 to $80 \%$ of (IWR). Generally, the highest root diameter was recorded with Oscar poly variety, when irrigated by full irrigation water requirement in both seasons.

\section{Root weight $(\mathrm{kg})$}

Data given in Table 6 reveled that root weight was significantly increased by increasing irrigation rate from $60-100 \%$ of the full irrigation water requirement (IWR) in the two seasons, these increments amounted by 0.591 , and $0.257 \mathrm{~kg} / \mathrm{plant}$ compared with irrigated by 60 and $80 \%$ (IWR) in the $1^{\text {st }}$ season, while these increases were 0.541 and $0.144 \mathrm{~kg} /$ plant in $2^{\text {nd }}$ season respectively. The increase in root weight by increasing irrigation rate is due to the increase in height and thickness of root (Tables 4, 5). This results are in agreement with those obtained by Masri et al. (2015), Mohamed \& El-Sebai (2019) and Abd El-All \& Makhlouf (2017) who noted that irrigating sugar beet with 100 ETc significantly increased root fresh weight.

Data presented in the same Table cleared that sugar beet varieties had significant effect on root weight. Roots of Oscar poly variety was heavier than that of the other two varieties in the two seasons. The superiority of Oscar poly over the other tested varieties in root weight may be due to its superiority in root height and diameter (Tables 4 and 5). These results are in harmony with those obtained by El-Emary (2017), Sadek et al. (2019) and Kandil et al. (2020), they found the examined varieties differed significantly in root fresh weight/plant in both seasons.

Interaction between irrigation rate and beet varieties had significant effect on root weight in both season. This means that the beet varieties did not behave the same at the different irrigation rate. In $2^{\text {nd }}$ season, root weight of Farida variety was significantly increased by increasing irrigation rate from 80 to $100 \%$ of (IWR) but this was not the case with the other two varieties. Generally the highest values of root weight (1.640 and $1.406 \mathrm{~kg} / \mathrm{plant}$ ) were obtained from irrigation sugar beet varieties Oscar poly with rate 100 of (IWR) in $1^{\text {st }}$ and $2^{\text {nd }}$ seasons, respectively.

\section{Root yield (ton/ha)}

Data in Table 7 showed that root yield was significantly affected by deficit irrigation level. Irrigation sugar beet plants with $100 \%$ of IWR recorded the highest root yield (65.450 and 63.694ton/ha.) in both $1^{\text {st }}$ and 2 nd seasons, respectively. The increase in root yield due to the increase in the root height diameter and weight (Tables 4, 5 and 6). Similar results were obtained by Tognetti et al. (2002), El Hamdi et al. (2017) and Nilahyane et al. (2020), they revealed that deficit irrigation significantly reduced the extractable sugar $\%$.

TABLE 6. Root weight (kg) of sugar beet varieties as affected by different deficit water levels in 2016/2017 and 2017/2018

\begin{tabular}{|c|c|c|c|c|c|c|c|c|}
\hline \multirow{3}{*}{$\begin{array}{l}\text { Irrigation } \\
\text { water } \\
\text { applied }\end{array}$} & \multirow{2}{*}{\multicolumn{3}{|c|}{$\begin{array}{c}2016 / 2017 \\
\text { Varieties }\end{array}$}} & \multirow{3}{*}{ Mean } & \multirow{2}{*}{\multicolumn{3}{|c|}{$\begin{array}{c}2017 / 2018 \\
\text { Varieties }\end{array}$}} & \multirow{3}{*}{ Mean } \\
\hline & & & & & & & & \\
\hline & Oscar poly & Farida & Universal & & Oscar poly & Farida & Universal & \\
\hline $60 \%$ & 0.970 & 0.840 & 0.874 & 0.895 & 0.940 & 0.865 & 0.887 & 0.897 \\
\hline $80 \%$ & 1.394 & 1.074 & 1.217 & 1.229 & 1.461 & 1.156 & 1.264 & 1.294 \\
\hline $100 \%$ & 1.640 & 1.455 & 1.363 & 1.486 & 1.535 & 1.406 & 1.374 & 1.438 \\
\hline Mean & 1.335 & 1.123 & 1.152 & & 1.312 & 1.142 & 1.175 & \\
\hline \multicolumn{9}{|c|}{ LSD.at 0.05 level for } \\
\hline \multicolumn{4}{|c|}{ Irrigation water applied (A) } & 0.074 & & & & 0.063 \\
\hline \multicolumn{4}{|c|}{ Sugar beet varieties (B) } & 0.109 & & & & 0.091 \\
\hline \multicolumn{4}{|l|}{$A \times B$} & 0.163 & & & & 0.124 \\
\hline
\end{tabular}


TABLE 7. Root yield (ton/ha) of sugar beet varieties as affected by different deficit water levels in 2016/2017 and 2017/2018

\begin{tabular}{|c|c|c|c|c|c|c|c|c|}
\hline \multirow{3}{*}{$\begin{array}{l}\text { Irrigation } \\
\text { water } \\
\text { applied }\end{array}$} & \multicolumn{3}{|c|}{ 2016/2017 } & \multirow{3}{*}{ Mean } & \multicolumn{3}{|c|}{$2017 / 2018$} & \multirow{3}{*}{ Mean } \\
\hline & \multicolumn{3}{|c|}{ Varieties } & & \multicolumn{3}{|c|}{ Varieties } & \\
\hline & Oscar poly & Farida & Universal & & Oscar poly & Farida & Universal & \\
\hline $60 \%$ & 41.395 & 36.795 & 36.859 & 38.350 & 39.984 & 36.414 & 37.445 & 37.948 \\
\hline $80 \%$ & 61.611 & 46.379 & 53.186 & 53.725 & 37.445 & 50.249 & 57.008 & 48.234 \\
\hline $100 \%$ & 71.717 & 66.085 & 58.548 & 65.450 & 68.289 & 62.166 & 60.626 & 63.694 \\
\hline Mean & 58.241 & 49.753 & 49.531 & & 48.573 & 49.610 & 51.693 & \\
\hline \multicolumn{9}{|c|}{ LSD.at 0.05 level for } \\
\hline \multicolumn{4}{|c|}{ Irrigation water applied (A) } & 4.702 & & & & 3.149 \\
\hline \multicolumn{4}{|c|}{ Sugar beet varieties (B) } & 5. 626 & & & & 4.398 \\
\hline \multicolumn{4}{|l|}{$\mathrm{A} \times \mathrm{B}$} & 9.489 & & & & 5.260 \\
\hline
\end{tabular}

Also data showed that the examined beet varieties varied significantly in root yield, these results were true in both seasons. The beet variety Oscar poly out yielding Farida and Universal varieties by 8.488 and 8.710 ton $/$ ha. in $1^{\text {st }}$ season, while, beet variety Universal out yielding Oscar poly and Farida varieties by 3.120 and 2.083ton/ ha. in $2^{\text {nd }}$ season, respectively. These result are in agreement with those obtained by Ahmed et al. (2017), Sadek et al. (2019) and El-Safy et al. (2020) who found that there was a significant difference among the three tested sugar beet varieties in root yield.

Concerning the interaction effect, it could be noted that the effect of the interaction between studied two factors in both seasons was significant. Root yield of Universal was insignificantly increased by increasing irrigation rate from 80 to $100 \%$ from full IWR, but this was not the case with the other two varieties. This note holds fairly true in both seasons. Generally, the highest root yield (71.717 and 68.289ton/ ha.) as well as the lowest values (36.795 and 36.414 ton/ha) was recorded by irrigation Oscar poly and Farida varieties by 100 and $60 \%$ in first and second seasons, respectively.

\section{Sucrose percentage}

Data illustrated in Table 8 indicated that the sucrose \% was significantly affected by the irrigation level in both seasons. Sucrose $\%$ was significantly increased by increasing irrigation levels up to $100 \%$ of irrigation water requirements. Irrigated sugar beet plants with $100 \%$ of IWR recorded the highest percentages of sucrose (19.46 and 19.24\%) in the first and second seasons, respectively, without significant difference between $60 \%$ and $80 \%$ of IWR. These findings are in line with those reported by Masri et al. (2015), El Hamdi et al. (2017), they reported that productivity of sucrose \% under deficit water was comparable. However, a slight increase was observed with $100 \%$ from IWR treatment as compared to $80 \%$ treatment followed by $60 \%$ treatment.

Results also indicated that the evaluated sugar beet varieties differed significantly in sucrose \% in the two seasons. Sugar beet universal variety recorded the highest value of sucrose $\%$ in $1^{\text {st }}$ and $2^{\text {nd }} 1^{\text {st }}$ seasons. The varietal differences may be attributed to the genetic constitutes of varieties and its interaction with environmental conditions. Similar findings were reviewed by Sadek et al. (2019) and Teama et al. (2019) who found significant differences among tested sugar beet varieties in sucrose percentage.

Sucrose \% was significantly affected by the interaction between the studied factors in both seasons. This means that the cane varieties did not behave the same at the different irrigation rate. In first season, sucrose percentage of Farida and Universal varieties were significantly increased by increasing irrigation rate 60 to $100 \%$ of IWR, but this was not the case with the third variety. In general, the highest values of sucrose percentage (21.85 and 22.10) were obtained from Universal variety when irrigated at rate of $100 \%$ of IWR in the first and second seasons, respectively. 
TABLE 8. Sucrose percentage of sugar beet varieties as affected by different deficit water levels in $2016 / 2017$ and 2017/2018

\begin{tabular}{|c|c|c|c|c|c|c|c|c|}
\hline \multirow{3}{*}{$\begin{array}{l}\text { Irrigation } \\
\text { water } \\
\text { applied }\end{array}$} & \multicolumn{3}{|c|}{$2016 / 2017$} & \multirow{3}{*}{ Mean } & \multicolumn{3}{|c|}{$2017 / 2018$} & \multirow{3}{*}{ Mean } \\
\hline & \multicolumn{3}{|c|}{ Varieties } & & \multicolumn{3}{|c|}{ Varieties } & \\
\hline & Oscar poly & Farida & Universal & & Oscar poly & Farida & Universal & \\
\hline $60 \%$ & 15.73 & 16.33 & 17.80 & 16.62 & 15.33 & 16.53 & 17.93 & 16.60 \\
\hline $80 \%$ & 15.23 & 16.47 & 18.07 & 16.59 & 15.63 & 16.33 & 18.03 & 16.67 \\
\hline $100 \%$ & 17.17 & 19.37 & 21.85 & 19.46 & 17.10 & 18.53 & 22.10 & 19.24 \\
\hline Mean & 16.04 & 17.39 & 19.24 & & 16.02 & 17.13 & 19.36 & \\
\hline \multicolumn{9}{|c|}{ LSD.at 0.05 level for } \\
\hline \multicolumn{4}{|c|}{ Irrigation water applied (A) } & 1.29 & & & & 1.13 \\
\hline \multicolumn{4}{|c|}{ Sugar beet varieties (B) } & 1.16 & & & & 1.09 \\
\hline \multicolumn{4}{|l|}{$A \times B$} & 2.43 & & & & 2.14 \\
\hline
\end{tabular}

Impurities\% (sodium, potassium and $\alpha$ - amino nitrogen percentages)

Data in Tables 9, 10 and 11 cleared that the impurities percentages (sodium, potassium and $\alpha$ - amino nitrogen percentages) were significantly affected by the irrigation rate in both seasons. It is clear from the data that impurities $\%$, gave the lowest mean values in the $1^{\text {st }}$ season were 2.428 sodium, 3.161 for potassium and 1.628 for $\alpha$ - amino nitrogen percentages, resulted from irrigation with $100 \%$ of IWR. The same respective values in the $2^{\text {nd }}$ season were, 3.203 for sodium, 3.869f or potassium and 1.834 for $\alpha$ amino nitrogen percentages, respectively. These results are in the same line with those obtained by Tognetti et al. (2002), Mahmoodi et al. (2008) and Masri et al. (2015) who found that impurities $\%$ were significantly affected by increasing water deficit from $100 \%$ up to $50 \%$ of the irrigation water requirements.

TABLE 9. Sodium \% of sugar beet varieties as affected by different deficit water levels in 2016/2017 and 2017/2018

\begin{tabular}{|c|c|c|c|c|c|c|c|c|}
\hline \multirow{3}{*}{$\begin{array}{l}\text { Irrigation } \\
\text { water } \\
\text { applied }\end{array}$} & \multirow{2}{*}{\multicolumn{3}{|c|}{$\begin{array}{c}2016 / 2017 \\
\text { Varieties }\end{array}$}} & \multirow{3}{*}{ Mean } & \multicolumn{3}{|c|}{$2017 / 2018$} & \multirow{3}{*}{ Mean } \\
\hline & & & & & \multicolumn{3}{|c|}{ Varieties } & \\
\hline & Oscar poly & Farida & Universal & & Oscar poly & Farida & Universal & \\
\hline $60 \%$ & 2.950 & 2.867 & 3.223 & 3.013 & 3.400 & 3.347 & 3.217 & 3.321 \\
\hline $80 \%$ & 3.000 & 2.717 & 3.243 & 2.987 & 3.363 & 3.220 & 3.160 & 3.248 \\
\hline $100 \%$ & 2.440 & 2.327 & 2.517 & 2.428 & 3.160 & 3.233 & 3.217 & 3.203 \\
\hline Mean & 2.797 & 2.637 & 2.994 & & 3.308 & 3.267 & 3.198 & \\
\hline \multicolumn{9}{|c|}{ LSD.at 0.05 level for } \\
\hline \multicolumn{4}{|c|}{ Irrigation water applied (A) } & 0.051 & & & & 0.072 \\
\hline \multicolumn{4}{|c|}{ Sugar beet varieties (B) } & 0.089 & & & & 0.094 \\
\hline \multicolumn{4}{|l|}{$\mathrm{A} \times \mathrm{B}$} & N.S & & & & N.S \\
\hline
\end{tabular}

TABLE 10. Potassium percentage of sugar beet varieties as affected by different deficit water levels in 2016/2017 and 2017/2018

\begin{tabular}{|c|c|c|c|c|c|c|c|c|}
\hline \multirow{3}{*}{$\begin{array}{l}\text { Irrigation } \\
\text { water } \\
\text { applied }\end{array}$} & \multirow{2}{*}{\multicolumn{3}{|c|}{$\begin{array}{c}2016 / 2017 \\
\text { Varieties }\end{array}$}} & \multirow{3}{*}{ Mean } & \multirow{2}{*}{\multicolumn{3}{|c|}{$\begin{array}{c}2017 / 2018 \\
\text { Varieties }\end{array}$}} & \multirow{3}{*}{ Mean } \\
\hline & & & & & & & & \\
\hline & Oscar poly & Farida & Universal & & Oscar poly & Farida & Universal & \\
\hline $60 \%$ & 5.333 & 3.600 & 4.017 & 4.317 & 4.197 & 4.160 & 4.153 & 4.170 \\
\hline $80 \%$ & 5.200 & 5.233 & 4.000 & 4.811 & 4.377 & 4.203 & 4.210 & 4.263 \\
\hline $100 \%$ & 3.800 & 2.737 & 2.947 & 3.161 & 4.147 & 3.747 & 3.713 & 3.869 \\
\hline Mean & 4.778 & 3.857 & 3.654 & & 4.240 & 4.037 & 4.026 & \\
\hline \multicolumn{9}{|c|}{ LSD.at 0.05 level for } \\
\hline \multicolumn{4}{|c|}{ Irrigation water applied (A) } & 0.574 & & & & 0.191 \\
\hline \multicolumn{4}{|c|}{ Sugar beet varieties (B) } & 0.729 & & & & NS \\
\hline \multicolumn{4}{|l|}{$\mathrm{A} \times \mathrm{B}$} & 1.218 & & & & 0.568 \\
\hline
\end{tabular}


TABLE 11. $\alpha$ - amino nitrogen percentage of sugar beet varieties as affected by different deficit water levels in 2016/2017 and 2017/2018

\begin{tabular}{|c|c|c|c|c|c|c|c|c|}
\hline \multirow{3}{*}{$\begin{array}{l}\text { Irrigation } \\
\text { water } \\
\text { applied }\end{array}$} & \multicolumn{3}{|c|}{$2016 / 2017$} & \multirow{3}{*}{ Mean } & \multicolumn{3}{|c|}{$2017 / 2018$} & \multirow{3}{*}{ Mean } \\
\hline & \multicolumn{3}{|c|}{ Varieties } & & \multicolumn{3}{|c|}{ Varieties } & \\
\hline & Oscar poly & Farida & Universal & & Oscar poly & Farida & Universal & \\
\hline $60 \%$ & 1.867 & 1.867 & 1.877 & 1.870 & 1.487 & 2.110 & 2.183 & 1.927 \\
\hline $80 \%$ & 1.600 & 1.767 & 2.303 & 1.890 & 2.283 & 2.090 & 2.100 & 2.158 \\
\hline $100 \%$ & 2.033 & 1.550 & 1.300 & 1.628 & 2.103 & 1.890 & 1.510 & 1.834 \\
\hline Mean & 1.833 & 1.728 & 1.827 & & 1.958 & 2.030 & 1.931 & \\
\hline \multicolumn{9}{|l|}{$\begin{array}{l}\text { LSD.at } 0.05 \\
\text { level for }\end{array}$} \\
\hline $\begin{array}{l}\text { Irrigation water } \\
\text { applied (A) }\end{array}$ & & & & 0.211 & & & & 0.103 \\
\hline $\begin{array}{l}\text { Sugar beet } \\
\text { varieties (B) }\end{array}$ & & & & N.S & & & & N.S \\
\hline$A \times B$ & & & & 0.809 & & & & 0.453 \\
\hline
\end{tabular}

The data in the same Tables showed that impurities characteristics percentages among studied sugar beet varieties, were significantly affected in both seasons except, $\alpha$ - amino nitrogen $\%$ in both seasons as well as potassium $\%$ in second season only. Farida and Universal varieties had the lowest mean values of sodium percentage in $1^{\text {st }}$ and $2^{\text {nd }}$ seasons, respectively. While Universal sugar beet variety recorded the lowest potassium percentage in both seasons. The variation of sodium and potassium percentages content between the studied varieties may be due to varietal characteristic. This result is in agreement with those found by Ahmed et al. (2017) and El-Emary (2017), who reported that sugar beet varieties differed significantly in impurities $\%$, i.e. sodium and potassium in both seasons.

Data also clearly showed that impurities percentages were significantly affected by the interaction between the two studied factors, in both seasons except sodium \%. Generally, the lowest potassium \% (2.737 and 3.713) were recorded by irrigated Farida and Universal varieties at rate of $100 \%$ of IWR in first and second seasons respectively. Meanwhile, the lowest $\alpha$ - amino nitrogen \% (1.300 and 1.510) were recorded by irrigated Universal at rate of $100 \%$ of IWR in the first and second seasons, respectively.

Sugar loss to molasses percentage (SLM\%)

Results in Table 12 disclose that sugar loss to molasses percentage was significantly affected by the examined irrigation rates. Lowest values
$(1.690 \%$ and $1.965 \%)$ were recorded when plants irrigated with $100 \%$ of IWR, in the first and second seasons, respectively. These results are in harmony with those obtained by Tognetti et al. (2002), Mahmoodi et al. (2008) and El Hamdi et al. (2017). They found that deficit irrigation level of $60 \%$ from IWR achieved the highest concentrations sugar loss to molasses $\%$.

The evaluated sugar beet varieties varied significantly in loss to molasses percentage, in the $1^{\text {st }}$ and $2^{\text {nd }}$ seasons. It could be noticed that Oscar poly variety recorded that highest values of this trait compared with the other ones. In addition, the variance between Farida and Universal varieties in this trait was not significant in both seasons. The variance among varieties in this trait may be due to their gene structure. These findings are in accordance with those found by Ahmed et al. (2017) and Mohamed \& El-Sebai (2019) who found that that sugar beet varieties differed significantly in loss to molasses \%.

The interaction between varieties and irrigation rate had a significant effect on sugar loss to molasses $\%$. The varieties did not behave the same under the evaluated irrigation rate. In the second season, sugar loss to molasses \% of Universal variety was significantly decreased by increasing irrigation rate from 80 to $100 \%$ of the full irrigation water requirement, but this was not true in the case of the other varieties. In general, the lowest sugar loss to molasses \% (1.590 and $1.848 \%$ ) was produced by Universal variety when irrigated with $100 \%$ of IWR in $1^{\text {st }}$ and $2^{\text {nd }}$ seasons, respectively. 
TABLE 12. Sugar loss to molasses percentage of sugar beet varieties as affected by different deficit water levels in 2016/2017 and 2017/2018

\begin{tabular}{|c|c|c|c|c|c|c|c|c|}
\hline \multirow{3}{*}{$\begin{array}{l}\text { Irrigation } \\
\text { water } \\
\text { applied }\end{array}$} & \multicolumn{3}{|c|}{$2016 / 2017$} & \multirow{3}{*}{ Mean } & \multicolumn{3}{|c|}{$2017 / 2018$} & \multirow{3}{*}{ Mean } \\
\hline & \multicolumn{3}{|c|}{ Varieties } & & \multicolumn{3}{|c|}{ Varieties } & \\
\hline & Oscar poly & Farida & Universal & & Oscar poly & Farida & Universal & \\
\hline $60 \%$ & 2.126 & 1.872 & 1.983 & 1.994 & 1.902 & 2.063 & 2.078 & 2.014 \\
\hline $80 \%$ & 2.048 & 2.055 & 2.090 & 2.064 & 2.155 & 2.062 & 2.057 & 2.091 \\
\hline $100 \%$ & 1.882 & 1.597 & 1.590 & 1.690 & 2.082 & 1.966 & 1.848 & 1.965 \\
\hline Mean & 2.019 & 1.841 & 1.888 & & 2.046 & 2.030 & 1.994 & \\
\hline \multicolumn{9}{|c|}{ LSD.at 0.05 level for } \\
\hline \multicolumn{4}{|c|}{ Irrigation water applied (A) } & 0.082 & & & & 0.012 \\
\hline \multicolumn{4}{|c|}{ Sugar beet varieties (B) } & 0.083 . & & & & 0.085 \\
\hline \multicolumn{4}{|l|}{$A \times B$} & 0.230 & & & & 0.128 \\
\hline
\end{tabular}

Extractable sugar percentage (ES\%)

The tabulated results in Table 13 showed that that increasing irrigation rate from 60 to $100 \%$ of IWR significantly affected the extractable sugar $\%$. However, a slight increase was observed with $80 \%$ from IWR treatment as compared to $60 \%$ in both seasons. This result is in agreement with those obtained by Mahmoodi et al.(2008), Masri et al. (2015) and Nilahyane et al. (2020), they revealed that deficit irrigation significantly reduced the extractable sugar $\%$.

Also data in the same Table showed that extractable sugar was significantly affected by tested sugar beet varieties in the two seasons. In general, extractable sugar percentage of Universal was higher than other varieties in both seasons. While the variety of Oscar poly gave the lowest extractable sugar percentage in first and second seasons. The differences among tested varieties in extractable sugar $\%$ is due to the differences in sucrose \% (Table 6). The effective role of sugar beet varieties on extractable sugar percentage has been reported by Mekdad \& El-Sherif (2016) and Mohamed \& El-Sebai (2019) who revealed that there were significant differences among sugar varieties of sugar extractable.

Extractable sugar \% was significantly affected by the interaction among two studied factors, tested varieties did not behave the same at the different deficit water levels, in the second season, extractable sugar \% of Oscar poly and Universal varieties were increased by increasing water levels from 60 to $80 \%$ from IWR, but this was not true in the case of Farida variety. In general, the highest extractable sugar \% (19.66 and 20.25\%) was produced by Universal variety when irrigated with $100 \%$ from IWR in $1^{\text {st }}$ and $2^{\text {nd }}$ seasons, respectively.

TABLE 13. Extractable sugar percentage (E S \%) of sugar beet varieties as affected by different deficit water levels in 2016/2017 and 2017/2018

\begin{tabular}{|c|c|c|c|c|c|c|c|c|}
\hline \multirow{2}{*}{$\begin{array}{l}\text { Irrigation } \\
\text { water } \\
\text { applied }\end{array}$} & \multicolumn{3}{|c|}{$2016 / 2017$} & \multirow[b]{2}{*}{ Mean } & \multicolumn{3}{|c|}{$2017 / 2018$} & \multirow[b]{2}{*}{ Mean } \\
\hline & \multicolumn{3}{|c|}{ Varieties } & & \multicolumn{3}{|c|}{ Varieties } & \\
\hline $60 \%$ & 13.67 & 14.46 & 15.82 & 14.63 & 13.43 & 14.47 & 15.86 & 13.98 \\
\hline $100 \%$ & 15.29 & 17.17 & 19.66 & 17.35 & 15.02 & 16.54 & 20.25 & 17.36 \\
\hline Mean & 14.03 & 15.55 & 20.26 & & 13.43 & 14.47 & 15.86 & \\
\hline \multicolumn{9}{|c|}{ LSD.at 0.05 level for } \\
\hline \multicolumn{4}{|c|}{ Irrigation water applied (A) } & 1.80 & & & & 1.69 \\
\hline
\end{tabular}




\section{Extractability}

Data in Table 14 showed that extractability $\%$ was affected significantly by the different deficit water levels. From results it could be seen that applying $100 \%$ of IWR to sugar beet increased extractability $\% 3.8 \%$ and $4.2 \%$, in the $1^{\text {st }}$ season, corresponding to $2.36 \%$ and $2.62 \%$, in the $2^{\text {nd }}$ one, compensate with 60 and/or $80 \%$ from IWR, respectively. These results are in agreement with those obtained by Tognetti et al. (2002), Mahmoodi et al. (2008) and Al-Sayed et al. (2014), they found that extractability $\%$ of sugar beet significantly affected by the examined irrigation rates.

Also, data showed that a significant difference was found among the evaluated sugar beet varieties in extractability \% in both seasons. The highest mean value of this trait was recorded by Universal variety, while the lowest was of Oscar poly variety. These results are probably attributed to the content of both sucrose and sugar lost to molasses, where the higher the sucrose $\%$ and the lower the sugar lost to molasses recorded by Universal variety (Tables 8 and 12). These findings are in line with those reported by Mohamed \& El-Sebai (2019) who found that the differences among the examined varieties were statistically significant with respect to extractability \% in both seasons.

As to, the effect of interaction among the two studied factors was significant in both seasons, it is clear that the extractability $\%$ of the tested varieties were not in the same line with the studied deficit water levels. In $2^{\text {nd }}$ season, extractability $\%$ of Farida and Universal varieties were increased by increasing water levels from 60 to $80 \%$ from IWR, but this was not true in the case of Oscar poly variety. Generally, the highest extractability \% (89.98 and $88.91 \%$ ) was produced by Universal variety when irrigated with $100 \%$ from IWR in $1^{\text {st }}$ and $2^{\text {nd }}$ seasons, respectively.

\section{Extractable sugar yield/ha. (ton/ha.)}

The collected data in Table 15 showed that extractable sugar yield (ton/fad) was significantly affected by deficit irrigation level. Decreasing the amount of irrigation water from $100 \%$ to $80 \%$ and $60 \%$ of IWR significantly decreased mean sugar yield by 32.66 and $51.36 \%$ in the $1^{\text {st }}$ season and by 23.80 and $49.61 \%$ in the $2^{\text {nd }}$ season, respectively. These results are in agreement with that given by Mahmoodi et al. (2008), El Hamdi et al. (2017) and Nilahyane et al. (2020), they reported that deficit irrigation significantly reduced the extractable sugar yield.

Data showed that the tested varieties differed significantly in extractable sugar yield in the both seasons. In the first season, Universal variety out yielded Oscar poly and Farida varieties in cane yield by 0.492 and 0.3530 .840 tons/ha., in first season, corresponding to 0.988 and 1.533 tons/ ha., in the second season, respectively. These results could be attributed to higher values of root yield and extractable sugar \% (Tables 6 and 13). The effective role of varieties on cane yield was reported by Ahmed (2017), Sadek et al.(2019), Teama et al. (2019) and Kandil et al. (2020) who found significant differences among tested sugar beet varieties in sugar yield.

TABLE 14. Extractability of sugar beet varieties as affected by different deficit water levels in 2016/2017 and 2017/2018

\begin{tabular}{|c|c|c|c|c|c|c|c|c|}
\hline \multirow{3}{*}{$\begin{array}{l}\text { Irrigation } \\
\text { water } \\
\text { applied }\end{array}$} & \multicolumn{3}{|c|}{ 2016/2017 } & \multirow{3}{*}{ Mean } & \multicolumn{3}{|c|}{ 2017/2018 } & \multirow{3}{*}{ Mean } \\
\hline & \multicolumn{3}{|c|}{ Varieties } & & \multicolumn{3}{|c|}{ Varieties } & \\
\hline & Oscar poly & Farida & Universal & & Oscar poly & Farida & Universal & \\
\hline $60 \%$ & 82.53 & 84.64 & 85.45 & 84.23 & 83.53 & 83.47 & 85.06 & 84.02 \\
\hline $80 \%$ & 82.57 & 83.85 & 85.08 & 83.83 & 82.36 & 83.66 & 85.26 & 83.76 \\
\hline $100 \%$ & 85.46 & 88.65 & 89.98 & 88.03 & 84.25 & 86.02 & 88.91 & 86.38 \\
\hline Mean & 83.52 & 85.71 & 86.84 & & 83.38 & 84.38 & 86.41 & \\
\hline \multicolumn{9}{|c|}{ LSD.at 0.05 level for } \\
\hline \multicolumn{4}{|c|}{ Irrigation water applied(A) } & 1.62 & & & & 1.00 \\
\hline \multicolumn{4}{|c|}{ Sugar beet varieties (B) } & 1.74 & & & & 1.65 \\
\hline \multicolumn{4}{|l|}{$\mathrm{A} \times \mathrm{B}$} & 2.42 & & & & 2.04 \\
\hline
\end{tabular}

Egypt. J. Agron. 43, No. 3 (2021) 
TABLE 15. Extractable sugar yield/fad (ton/ha.) of sugar beet varieties as affected by different deficit water levels in 2016/2017 and 2017/2018

\begin{tabular}{|c|c|c|c|c|c|c|c|c|}
\hline \multirow{3}{*}{$\begin{array}{l}\text { Irrigation } \\
\text { water } \\
\text { applied }\end{array}$} & \multicolumn{3}{|c|}{ 2016/2017 } & \multirow{3}{*}{ Mean } & \multicolumn{3}{|c|}{$2017 / 2018$} & \multirow{3}{*}{ Mean } \\
\hline & \multicolumn{3}{|c|}{ Varieties } & & \multicolumn{3}{|c|}{ Varieties } & \\
\hline & Oscar poly & Farida & Universal & & Oscar poly & Farida & Universal & \\
\hline $60 \%$ & 5.674 & 5.315 & 5.831 & 5.607 & 5.334 & 5.276 & 5.938 & 5.516 \\
\hline $80 \%$ & 8.135 & 6.669 & 8.489 & 7.764 & 8.754 & 7.157 & 9.113 & 8.341 \\
\hline $100 \%$ & 10.946 & 11.729 & 11.912 & 11.529 & 10.274 & 10.294 & 12.276 & 10.948 \\
\hline Mean & 8.252 & 7.904 & 8.744 & & 8.121 & 7.576 & 9.109 & \\
\hline \multicolumn{9}{|c|}{ LSD.at 0.05 level for } \\
\hline \multicolumn{4}{|c|}{ Irrigation water applied(A) } & 0.699 & & & & 0.531 \\
\hline \multicolumn{4}{|c|}{ Sugar beet varieties (B) } & 0.771 & & & & 0.719 \\
\hline \multicolumn{4}{|l|}{$A \times B$} & 1.771 & & & & 1.816 \\
\hline
\end{tabular}

The results revealed that Extractable sugar yield was affected significantly by the interactions between cane varieties with irrigation levels on both seasons. Varieties did not behave the same under the three irrigation levels. Extractable sugar yield of Farida variety was insignificantly increased by increasing irrigation levels from 60 to 80 of IWR but this was not the case with the other two varieties. Generally, the highest sugar yield (11.912 and 12.276tons /ha.) was recorded by irrigated Universal variety at rate of $100 \%$ of IWR in first and second seasons, respectively.

\section{Conclusion}

Evalution sugar beet cultivation and production under water stress, in Toshka region which represent the dry climate with the newly reclaimed soils recommended to use $8877 \mathrm{~m}^{3} / \mathrm{ha}$., also led to the following:

- The results showed significant increase in root and sugar yields by increasing irrigation water levels from $60 \%$ up to 80 and $100 \%$ of irrigation water requirements (IWR)

- Results illustrated that the highest value of roots and sugar yield were recorded by Oscar poly and Universal sugar beet varieties in first and second seasons respectively.

- The results suggested that planting Universal sugar beet variety, with 100 of the full irrigation water requirement can be recommended to produce the best quality as well as the highest root and sugar yields/fad.

\section{Reffrences}

Abd El-All, A.E.A., Makhlouf, B.S.I. (2017) Response of sugar beet to continuous deficit irrigation and foliar application of some micronutrients under sandy soil conditions. Journal of Soil Sciences and Agricultural Engineering, Mansoura Univ. 8(12), 749-760.

Ahmed, A.Z., Awadalla, A.O., Abazid, Sakina, R. (2017) Possibility of sugar beet production in Toshka Region. I-Assessment of the optimum harvesting age. Journal of Plant Production, Mansoura Univ. 8(12), 1409-1415.

Al-Sayed, H.M., Osman, A.Sh.A., ElAdway, Sh.B.I. (2014) Effects of irrigation water quality and application rates of sprinkler irrigation on yield and quality of some sugar beet varieties. Egyptian Journal of Applied Sciences, 29(5), 158-177.

Attaya, S.A. (2017) Influence of drip irrigaton rates and soil improvers on the performance of some sugar beet varieties in North Sinai. Zagazig Journal of Agricultural Research, 44(2), 419-435.

A.O.A.C. (2005) Association of Official Analytical Chemists. "Official Methods of Analysis", $16^{\text {th }}$ ed. Inter. Washington, D. C. USA.

Blaney, H.F., Criddle, W.D. (1962) Determining consumptive use and irrigation water requirements, USDA Technical Bulletin 1275. US Depart. Agric. Beltsville.

Devillers, P. (1988) Prevision du sucre melasse. Scurries francases 129, 190-200. (C.F. The Sugar

Egypt. J. Agron. 43, No. 3 (2021) 
Beet Crop Book).

Dexter, S.T., Frakes, M.G., Snyder, F.W. (1967) A rapid and practical method of determining extractable white sugar as may be applied to the evaluation of agronomic practices and grower deliveries in the sugar beet industry. Journal of the American Society of Sugar Beet Technologists, 14, 433-454.

Doorenbos J., Kassam, A.H. (1979) Yield Response to Water. FAO Irrigation and Drainage Paper No. 33, Rome, Italy.

El-Emary, F.A.A. (2017) Botanical characteristics of some sugar beet varieties (Beta vulgaris L) comparative study. Journal of Plant Production, Mansoura Univ. 8(3), 397 -403.

El Hamdi, Kh.H., El-Shazly, M.M., Mosa, A.A., El Dereny, M.E.R. (2017) Water use efficiency, yield and quality of sugar beet grown under center pivot and fixed sprinkler irrigation systems as affected by water deficit and boron application. Journal of Soil Sciences and Agricultural Engineering, Mansoura Univ. 8(3), 133 - 138.

El-Safy, Nadia K., El-Sharnoby, H.M., El-Sheikh, A.M. (2020) Response of some sugar beet varieties to abscisic acid under different storage periods. Egyptian Academic Journal of Biological Sciences, H. Botany, 11(2), 41-51.

Kandil, A.A., Sharief, A.E.M., Abdullah, A.M.A. (2020) Effect of bio and mineral nitrogen fertilization on growth and quality of some sugar beet cultivars. International Journal of Advanced Research in Biological Sciences, 7(10), 1-10.

Mahmoodi, R., Maralian, H., Aghabarati, A. (2008) Effects of limited irrigation on root yield and quality of sugar beet (Beta vulgaris L.). African Journal of Biotechnology, 7(24), 4475-4478.

Masri, M.I., Ramadan, B.S.B., El-Shafai, A.M.A., El-Kady, M.S. (2015) Effect of water stress and fertilization on yield and quality of sugar beet under drip and sprinkler irrigation systems in sandy soi. International Journal of Agricultural Science, 5(3), 414-425.
Mekdad,A.A.A., El-Sherif, A.M.A. (2016) Performance of two sugar beet varieties under fertilization with potassium and foliar spraying with micronutrients. Egyptian Journal of Agronomy, 38(2), 189 -207.

Mohamed, Hanan Y., El-Sebai, T.N. (2019) Effect of bio-stimulant (phosphate solubilizing microorganisms) on yield and quality of some sugar beet varieties. Egyptian Journal of Applied Sciences, 34(7), 114-129.

Nilahyane, A., Chen, C., Afshar, R.K., Sutradhar, A., Stevens, W.B., Iversen, W. (2020) Deficit irrigation for sugarbeet under conventional and no-till production. Agrosystems, Geosciences \& Environment, 3(1), 1-11.

Sadek, K.A., Makhlouf, B.S.I., Fadel, A.M.E., ElSherief, Amira E. (2019) Response of some sugar beet varieties grown under different saline soils and plant populations. Alexandria Journal of Agricultural Science, 64(6), 399-407.

Smith, N. (1991) CROPWAT model for ETo calculation using penman monteith method. FAO.

Snedecor, G.W., Cochran, W.G. (1981) "Statistical Methods". Oxfored and I.B.H. puplishing G. $6^{\text {th }}$ ed., pp. 299-310.

Steel, R.G.D., Torrie, J.H. (1980) "Principles and Procedures of Statistics". Mc Grow-Hill Book Co. Inc., New York.

S. C. C. (2020) Sugar Crops council Ministry of Agric., Egypt Ann. Report. (In Arabic).

Teama, E.A., Dawood, R.A., Osman, A.A., Ahmed, A.Z., Youssef, A.M.M. (2019) Yield and quality of three sugar beet varieties as affected by titanium dioxide nanoparticles foliar application and nitrogen fertilization. Egyptian Sugar Journal, 13, $1-27$.

Tognetti, R., Delfine, S., Sorella, P., Alvino, A. (2002) Responses of sugar beet to drip and low-pressure sprinkler irrigation systems: Root yield and sucrose accumulation. Agric. Mediterranean, 132(1), 1-8. 


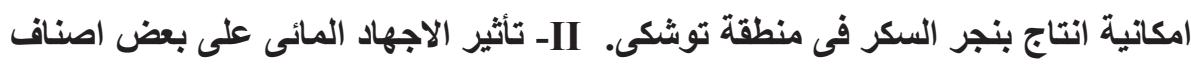

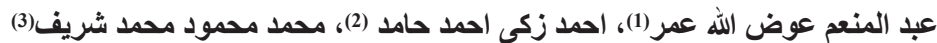

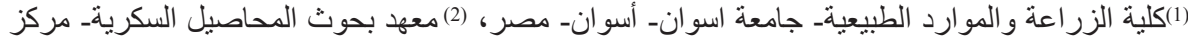

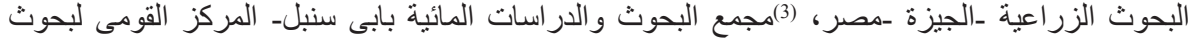

هذا هو العمل البحثى الثانى الذى يتتاول بنجر السكر فى منطقة توشكى لدر اسة امكانية انتاجه بها، حيث تم إجر اء

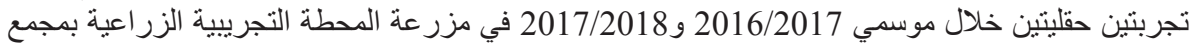

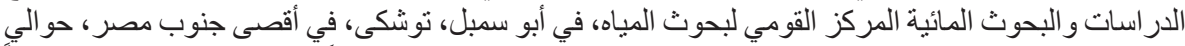

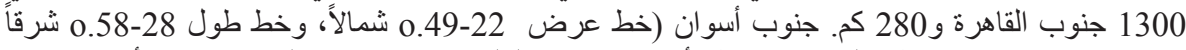

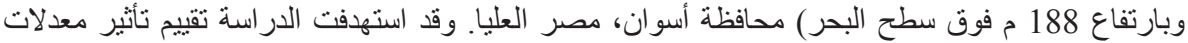

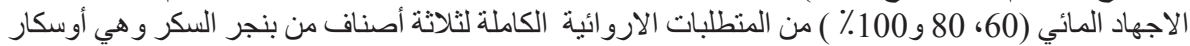

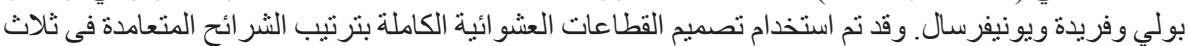
مكررات.

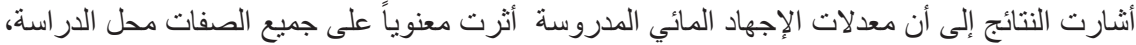

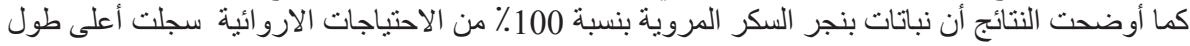

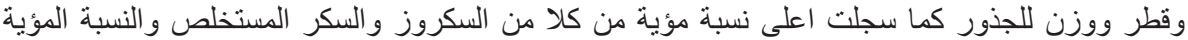

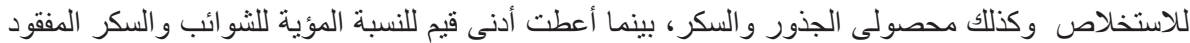

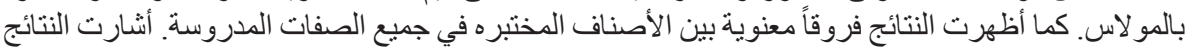

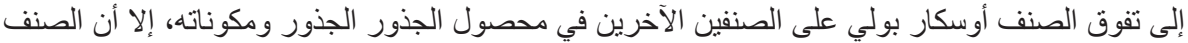

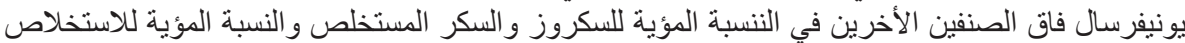
ومحصول السكر.

تحت ظروف منطقة توشكى ، أشارت النتائج إلى امكانية التوصية بزر اعة صنف إنف بنجر السكر مع ريه بنسبة

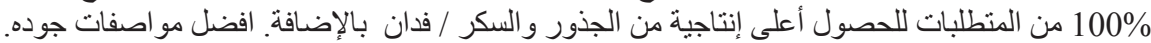

